\title{
Plastics in Marine Environment
}

\author{
Korkmaz C ${ }^{1 *}$, Ay $0^{1}$ and Erdem C 2 \\ ${ }^{1}$ Mersin University, Faculty of Fisheries, 33169, Yenişehir, Mersin, Turkey \\ ${ }^{2}$ Çukurova University, Faculty of Science and Letters, 01330, Sarıçam, Adana, Turkey
}

Review Article

Volume 2 Issue 2

Received Date: January 19, 2018

Published Date: February 14, 2018

*Corresponding author: Cengiz Korkmaz, Mersin University, Faculty of Fisheries, 33169, Yenișehir, Mersin, Turkey, Tel:

0 (546) 40187 05; Email: cengizkorkmaz@mersin.edu.tr

\section{Abstract}

Plastic debris are widespread and a growing problem in the marine environment. Due to resistance to degradation, plastic wastes are highly problematic for ecosystems. Today over 700 marine species from fish to birds and mammals etc., are estimated to be affected by plastic pollution. This review focuses on a short history of plastic usage in world and primer effects of plastic debris to marine invertebrates and vertebrates.

Keywords: Plastics; Marine; Pollution; Fish; Seabird

Abbreviations: PE: Polyethylene; PP: Polypropylene; PVC: Polyvinyl Chloride; PS: Polystyrene; PET: Polyethylene Terephthalate.

\section{Introduction}

Plastics are synthetic organic materials, which are obtained from polymerization of monomers extracted from oil or gas [1]. Modern plastic technology which started with the production of first plastic material; "Bakelite" in 1907, showed a rapid growth in the last century [2]. Due to low production costs, plastics are used in sectors such as automotive, construction, packaging, agriculture, clothing, electronics etc., and took place in almost all aspects of our lives. It was estimated that 275 million tons of plastic materials were produced in 192 coastal countries in the year 2010 and that 8 million tons of these manufactured plastics entered the world oceans. A tenfold increase in the amount of plastic litter reaching to oceans was predicted by the year 2020 [3].

Plastics are produced from organic and inorganic raw materials such as silicon, hydrogen; oxygen and chloride derived from gasoline and natural gases [4]. They are used in various areas of industry because of their low cost, light weight and durability [5]. Plastics have already replaced with conventional materials such as paper, glass and metal in packaging industry [6]. Although the mass production of plastics was began in 1940's, a rapid increase was observed in its global production which reached 322 million tons in 2015 [7]. Today, most widely used forms of plastics are: high and low-density polyethylene (PE), polypropylene (PP), polyvinyl chloride (PVC), polystyrene (PS) and polyethylene terephthalate (PET). These forms of plastics consist nearly $90 \%$ of global plastic manufacturing [8].

Although, high durability of plastics makes them such a convenient material for industry, these materials are highly resistant to degradation, therefore discarding the plastic litter is highly problematic from the environmental point of view [9]. The existence of plastic debris when first reported by Carpetner et al. [10], the scientific community, however, showed little attention to those wastes. Dramatic increase in the presence of plastic debris in North Pacific gyre, "plastic pollution" became a high-priority field of study in "Marine Biology" [6]. 


\section{International Journal of Oceanography \& Aquaculture}

Plastic wastes are divided into two groups; macroplastics and microplastics. Macroplastics are visible wastes with naked-eye and their negative effects on environment have long been known by scientific community. Macroplastics show their negative impacts on aesthetic concerns and consequently economic losses in tourism sector [2]. Moreover, macroplastics cause some injuries and disabilities to fish, sea turtles, sea birds and mammals by tangling to their extremities or mistakenly taken as food [11]. Whereas microplastics, although defined differently in literature, generally described as particles smaller than $5 \mathrm{~mm}$ in size [12]. Microplastics can be found in beaches, sediments, surface waters and all along the water column and can be dispersed into any wetland [13]. They can be found anywhere in food chain from primary producers to the upper levels of the chain [14]. The number of sea animals effected from plastic pollution rise from 250 in 1997 to 693 in 2015 [15].

\section{Influences of Plastic Wastes to Aquatic Organisms}

Plastic wastes show their basic effects physically by blocking circulation and digestive channels [13]. They effect the distribution and dispersion of mosquitoes by providing them suitable media for laying eggs [16]. Additionally, due to their monomer constituents, they can cause liver damages [17], behavioral changes [18], carcinogenic [13] and endocrine disrupting effects [19]. It was suggested that plastic materials also play a role in diffusion of phthalates, bisphenol A, formaldehyde, acetaldehyde and 4-noniphenol into tissues of aquatic organisms [20].

\section{Invertebrates}

Thompson, et al. [21] had stated that Orchestia gammarellus, Arenicola marina and Semibalanus balanoides fed with microplastic materials. Watts, et al. [22] reported that Carcinus meanas swallow microplastics as feeding materials and accumulate them in their gill spaces. Mytilus edulis, accepted as model organism in microplastic pollution, is shown to accumulate high levels of microplastics in laboratory studies [23-25]. Monofilament plastic fibers were found in intestine tissue of Nephrops norvegicus of which digestive tissue could not eliminate these fibres [26]. Various studies have shown that planktonic organisms such as Scenedesmus spp., Tigriopus japonicus and Dosidicus gigas can take plastic materials to their digestive tracks [27-29].

Laboratory studies on some tunicates, cnidarians and mollusk species have shown that they can accumulate micro plastics sized 1.7-30.6 nm in size [30]. Graham and Thompson [31] have suggested that some species of sea cucumbers (Echinodermata, Holothuroidea)can take nylon and PVC pieces into their digestive track and since plastic materials can absorbe polychlorinated biphenyl's (PCB) they can be an agent to transport PCB's to upper trophic levels.

\section{Vertebrates}

Boerger, et al. [32] reported that $35 \%$ of planktivory fish species from North Pacific gyre had microplastic materials in their stomach constituents. Lusher, et al. [33] pointed out that $36 \%$ of fish species from English Channel included synthetic or semi-synthetic plastic materials in their stomach content. In a similar study, stomach content of $9 \%$ of the fish species belonging to Myctophidae collected from North Pacific contained plastic materials [34]. Ramos, et al. [35] reported microplastic residues from $13.4 \%$ of Gerreidae caught from North East Brazil. Plastic materials in stomach contents of fish species were also expressed by other researchers $[36,37]$.

Sea birds are known to be the most effected organisms from plastic pollution and are used as biomonitoring organisms for a long while [14]. Provencher, et al. [38] indicated plastic contamination was determined in more than $80 \%$ of Fulmarus glacialis colonies from North Canada. Same findings were verified for $F$. glacialis by studies in North Iceland [39]. 83\% of Calonectris diomedea obtained from North Atlantic Ocean were reported to have plastics in their guts [40]. Blight and Burger [41] recorded plastics in 75\% of Puffinus griseus from eastern North Pacific. However, studies carried out in recent years reported that plastic pellets swallowed by sea birds showed a relative decrease [42-44].

Other studies carried on sea turtles [45-47] and on sea mammalians $[48,49]$ showed presence of plastic residues in stomach contents which affected them significantly.

\section{Conclusion}

The use of plastic materials increasing rapidly in areas such as garment, cosmetics and construction and as a consequence plastic wastes enter seas and oceans in excessive amounts at consequent years. Plastic wastes are estimated to effect around 700 organisms from planktonic organisms to fish and to sea mammals. Plastic materials can be present at all levels of organization and can be transferred to humans through food chain. Hence, it is necessary to follow up the plastic pollution routinely and to follow its impacts on ecosystems. 


\section{International Journal of Oceanography \& Aquaculture}

\section{References}

1. Rios LM, Moore C, Jones PR (2007) Persistent organic pollutants carried by synthetic polymers in the ocean environment. Marine Pollution Bulletin 54(8): 12301237.

2. Cole M, Lindeque P, Halsband C, Galloway TS (2011) Microplastics as contaminants in the marine environment: a review. Marine pollution bulletin 62(12): 2588-2597.

3. Jambeck JR, Geyer R, Wilcox C, Siegler TR, Perryman $M$, et al. (2015) Plastic waste inputs from land into the ocean. Science 347(6223): 768-771.

4. Shah AA, Hasan F, Hameed A, Ahmed S (2008) Biological degradation of plastics: a comprehensive review. Biotechnology advances 26(3): 246-265.

5. Andrady AL (Ed.) (2003) Plastics and the Environment. John Wiley \& Sons, pp: 747.

6. Andrady AL (2011) Microplastics in the marine environment. Marine pollution bulletin 62(8): 15961605.

7. Plastics Europe (2016) Plastics - The Facts 2016. An Analysis of European Plastics Production, Demand and Waste Data for 2016 (20/10/2016).

8. Andrady AL, Neal MA (2009) Applications and societal benefits of plastics. Philos Trans R Soc Lond B Biol Sci 364(1526): 1977-1984.

9. Barnes DK, Galgani F, Thompson RC, Barlaz M (2009) Accumulation and fragmentation of plastic debris in global environments. Philos Trans R Soc Lond B Biol Sci 364(1526): 1985-1998.

10. Carpenter EJ, Anderson SJ, Harvey GR, Miklas HP, Peck BB (1972) Polystyrene spherules in coastal waters. Science 178(4062): 749-750.

11. Lusher AL, Hernandez-Milian G, O'Brien J, Berrow S, O'Connor I, et al. (2015) Microplastic and macroplastic ingestion by a deep diving, oceanic cetacean: The True's beaked whale Mesoplodonmirus. Environmental Pollution 199: 185-191.

12. Barboza LGA, Gimenez BCG (2015) Microplastics in the marine environment: current trends and future perspectives. Marine pollution bulletin 97(1): 5-12.
13. Wright SL, Thompson RC, Galloway TS (2013) The physical impacts of microplastics on marine organisms: a review. Environ Pollut 178: 483-492.

14. Do Sul JAI, Costa MF (2014) The present and future of microplastic pollution in the marine environment. Environ Pollut 185: 352-364.

15. Gall SC, Thompson RC (2015) The impact of debris on marine life. Mar Pollut Bull 92(1): 170-179.

16. Majer AP, Vedolin MC, Turra A (2012) Plastic pellets as ovipositor site and means of dispersal for the ocean-skater insect Halobates. Mar Pollut Bull 64(6): 1143-1147.

17. Rochman CM, Hoh E, Kurobe T, Teh SJ (2013) Ingested plastic transfers hazardous chemicals to fish and induces hepatic stress. Scientific Reports 3: 3263.

18. Browne MA, Niven SJ, Galloway TS, Rowland SJ, Thompson RC (2013) Microplastic moves pollutants and additives to worms, reducing functions linked to health and biodiversity. Current Biology 23(23): 2388-2392.

19. Rochman CM, Kurobe T, Flores I, Teh SJ (2014) Early warning signs of endocrine disruption in adult fish from the ingestion of polyethylene with and without sorbed chemical pollutants from the marine environment. Sci Total Environ 493: 656-661.

20. Rochman CM (2015) The complex mixture, fate and toxicity of chemicals associated with plastic debris in the marine environment. Marine anthropogenic litter 117-140.

21. Thompson RC, Olsen Y, Mitchell RP, Davis A, Rowland SJ, et al. (2004) Lost at sea: where is all the plastic? Science 304(5672): 838-838.

22. Watts A, Lewis C, Goodhead RM, Beckett DJ, Moger J, et al. (2014) Uptake and retention of microplastics by the shore crab Carcinusmaenas. Environmental Science \& Technology 48(15): 8823-8830.

23. Browne MA, Dissanayake A, Galloway TS, Lowe DM, Thompson RC (2008) Ingested microscopic plastic translocates to the circulatory system of the mussel, Mytilusedulis(L.). Environ Sci Technol 42(13): 50265031.

24. Von Moos N , Burkhardt-Holm P , Köhler A (2012) Uptake and effects of microplastics on cells and tissue of the blue mussel Mytilus edulis L. after an 


\section{International Journal of Oceanography \& Aquaculture}

experimental exposure. Environ Sci Technol 46(20): 11327-11335.

25. Wegner A, Besseling E, Foekema EM, Kamermans P, Koelmans AA (2012) Effects of nanopolystyrene on the feeding behaviour of the blue mussel (Mytilusedulis L.). Environ Toxicol Chem 31: 24902497.

26. Murray F, Cowie PR (2011) Plastic contamination in the decapod crustacean Nephropsnorvegicus(Linnaeus, 1758). Mar Pollut Bull 62(6): 1207-1217.

27. Bhattacharya P, Turner JP, Ke PC (2010) Physical adsorption of charged plastic nanoparticles affects algal photosynthesis. J Phys Chem C 114(39): 1655616561.

28. Braid HE, Deeds J, De Grasse SL, Wilson JJ, Osborne J, et al. (2012) Preying on commercial fisheries and accumulating paralytic shellfish toxins: a dietary analysis of invasive Dosidicusgigas (Cephalopoda Ommastrephidae) stranded in Pacific Canada. Marine Biology 159(1): 25-31.

29. Lee KW, Shim WJ, Kwon OY, Kang JH (2013) Sizedependent effects of micro polystyrene particles in the marine copepod Tigriopus japonicus. Environ Sci Technol 47(19): 11278-11283.

30. Cole M, Lindeque P, Fileman E, Halsband C, Goodhead $\mathrm{R}$, et al. (2013) Microplastic ingestion by zooplankton. Environ Sci Technol 47(12): 6646-6655.

31. Graham ER, Thompson JT (2009) Deposit-and suspension-feeding sea cucumbers (Echinodermata) ingest plastic fragments. Journal of Experimental Marine Biology and Ecology 368(1): 22-29.

32. Boerger CM, Lattin GL, Moore SL, Moore CJ (2010) Plastic ingestion by planktivorous fishes in the North Pacific Central Gyre. Marine pollution bulletin 60(12): 2275-2278.

33. Lusher AL, McHugh M, Thompson RC (2013) Occurrence of microplastics in the gastrointestinal tract of pelagic and demersal fish from the English Channel. Marine pollution bulletin 67(1): 94-99.

34. Davison P, Asch RG (2011) Plastic ingestion by mesopelagic fishes in the North Pacific Subtropical Gyre. Marine Ecology Progress Series 432: 173-180.
35. Ramos JAA, Barletta M, Costa Monica F (2012) Ingestion of nylon threads by Gerreidae while using a tropical estuary as foraging grounds. Aquat Biol 17: 29-34.

36. Dantas DV, Barletta M, Da Costa MF (2012) The seasonal and spatial patterns of ingestion of polyfilament nylon fragments by estuarine drums (Sciaenidae). Environ Sci Pollut Res Int 19(2): 600606.

37. Foekema EM, De Gruijter C, Mergia MT, Van Franeker JA, Murk TJ, et al. (2013) Plastic in north sea fish. Environ Sci Technol 47(15): 8818-8824.

38. Provencher JF, Gaston AJ, Mallory ML (2009) Evidence for increased ingestion of plastics by northern fulmars (Fulmarusglacialis) in the Canadian Arctic. Mar Pollut Bull 58(7): 1092-1095.

39. Kühn S, Van Franeker JA (2012) Plastic ingestion by the northern fulmar (Fulmarusglacialis) in Iceland. Marine pollution bulletin 64(6): 1252-1254.

40. Rodríguez A, Rodríguez B, Carrasco MN (2012) High prevalence of parental delivery of plastic debris in Cory's shearwaters (Calonectrisdiomedea). Mar Pollut Bull 64(10): 2219-2223.

41. Blight LK, Burger AE (1997) Occurrence of plastic particles in seabirds from the eastern North Pacific. Marine Pollution Bulletin 34(5): 323-325.

42. Vlietstra LS, Parga JA (2002) Long-term changes in the type, but not amount, of ingested plastic particles in short-tailed shearwaters in the Southeastern Bering Sea. Mar Pollut Bull 44(9): 945-955.

43. Ryan PG (2008) Seabirds indicate changes in the composition of plastic litter in the Atlantic and southwestern Indian Oceans. Marine Pollution Bulletin 56(8): 1406-1409.

44. Van Franeker JA, Blaize C, Danielsen J, Fairclough K, Gollan J, et al. (2011) Monitoring plastic ingestion by the northern fulmar Fulmarusglacialis in the North Sea. Environmental Pollution 159(10): 2609-2615.

45. Tourinho PS, Ivar do Sul JA, Fillmann G (2010) Is marine debris ingestion still a problem for the coastal marine biota of southern Brazil. Marine Pollution Bulletin 60(3): 396-401. 


\section{International Journal of Oceanography \& Aquaculture}

46. Lazar B, Gračan R (2011) Ingestion of marine debris by loggerhead sea turtles, Carettacaretta, in the Adriatic Sea. Marine pollution bulletin 62(1): 43-47.

47. Schuyler Q, Hardesty BD, Wilcox C, Townsend K (2014) Global analysis of anthropogenic debris ingestion by sea turtles. Conservation biology 28(1): 129-139.
48. Eriksson C, Burton H (2003) Origins and biological accumulation of small plastic particles in fur seals from Macquarie Island. Ambio 32(6): 380-384.

49. Rebolledo ELB, Van Franeker JA, Jansen OE, Brasseur SM (2013) Plastic ingestion by harbour seals (Phocavitulina) in The Netherlands. Marine Pollution Bulletin 67(1): 200-202. 